\title{
Analisis kualitas pelayanan bartender/bartendres dalam meningkatkan kepuasan wisatawan pada sea fire salt bar di anantara uluwatu resort \& spa bali
}

\author{
Azwar Z1), Agus Muriawan Putra ${ }^{2)}$, Putu Ratih Pertiwi ${ }^{3}$ ) \\ Program Studi Diploma IV Pariwisata, Fakultas Pariwisata, Universitas \\ Udayana $^{123}$ Jalan Dr.Goris nomor 7 Denpasar, Bali
}

az_war62@yahoo.com

\begin{abstract}
Abstrak
Penelitian ini dilatarbelakangi oleh kualitas pelayanan bartender/bartendres yang harus memberikan pela yana yang baik kepada wisatawan dengan memberikan pelayanan yang baik. Tujuan penelitian ini adalah untuk mengetahui tentang kualitas pelayanan bartender/bartendres serta kriteria kepuasan wisatawan terhadap pelayanan bartender/bartendres pada Sea Fire Salt Bar di Anantara uluwatu Resort \& Spa Bali. Teknik pengumpulan data dalam penelitian ini menggunakan metode observasi, wawancara, kuesioner dan studi kepustakaan. Da ta dianalisis dengan Analisis Deskriptif Kuantitatif, Skala Likert dan Importance- Performance Analysis. Hasil penelitian ini menunjukan bahwa tingkat kualitas pelayanan bartender/bartendres telah diharapkan mampu meningkatkan kepuasan wisatawan. Hasil penelitian terhadap 100 orang wisatwan dan penilaian kinerja yang mempengaruhi tingkat kepuasan wisatawan terhadap kualitas pelayanan bartender/bartendres pada Sea Fire Salt di Anantara Uluwatu Resort \& Spa Bali diperoleh penilaian kinerja kua litas pelayanan dikategorik an baik terhadap kepuasan Wisa tawan. Da ri Lima (5) indikator, seluruh indikator mendapatkan skor sa ma yang dikatakan baik, dan tidak a da yang menjawab sangat baik. Sedangkan penilaian kepentingan yang mempengaruhi tingkat kepuasan wisatawan terhadap kualitas pelayanan bartender/bartendres pa da Sea Fire Salt di Anantara Uluwatu Resort \& Spa Bali diperoleh penilaian kinerja kualitas pelayanan dika tegorikan penting dan sangat penting terhadapkepuasan wisatawan.Saran yang dapat diberikan terhadap kualitas pelayanan bartender/bartendres harus terus ditingkatkan agar wisatawan yang berkunjung mendapatkan kepuasan dan pengunjung tersebut diharapkan nantinya kembali la gi mengunjungi Sea Fire Salt Bar di Anantara Uluwatu Resort \& Spa Bali.
\end{abstract}

Kata Kunci : Kualitas Pelayanan, Keuasan Wisatawan, Bartender/Bartendres

\begin{abstract}
This resea rch is motivated by the quality of service bartenders / bartendres who must provide good service to tourists by providing good service. The purpose of this study was to find out about the quality of bartender/ bartendres services and tourist sa tisfaction criteria for bartender/bartendres services at the Sea Fire Salt Bar at Anantara Uluwatu Resort \& Spa Bali. Data collection techniques in this study used the method of observation, interviews, questionnaires and literature studies. Data were analyzed with Quantitative Descriptive Analysis, Likert Scale and Importance - Performance Analysis. The results of the study of 100 tourists from performance appraisal that affected the level of tourist satisfaction with the service quality of bartenders / bartendres at Sea Fire Salt in Anantara Uluwatu Resort \& Spa Bali obtained an assessment of service quality performance categorized as good for tourist sa tisfaction. Of the five(5) indicators, all indicators get the same score that is said to be good, and no one answers very well. While the assessment of interests that affect the level of tourist satisfaction with the service quality of bartenders / bartendres at Sea Fire Salt in Anantara Uluwatu Resort \& Spa Baliobtained an assessment of service quality performance categorized as important and very important to tourist satisfaction.Suggestions that can be given to the quality of service of the bartender / bartendres must continue to be improved so that tourists who visit get sa tisfaction and visitors are expected to return to visit the Sea Fire Salt Bar at Anantara Uluwatu Resort \& Spa Bali
\end{abstract}

Keywords : Service Quality, Tourist Satisfaction, Bartender/Bartendres 


\section{PENDAHULUAN}

Bali merupakan salah satu daerah tujuan wisata yang terkenal di kalangan wisatawan mancanegara maupun domestik karena Bali memiliki kekayaan alam budaya yang unik. berkembangnya industri pariwisata seperti: hotel, restaurant, bar, travel agent dan sarana akomodasi lainya sangat membawa dampak yang sangat baik untuk industry pariwisata Bali.Pariwisata adalah salah satu kegiatan yang universal yang didorong oleh rasa ingin tahu manusia untuk menikmati hal baru, tempat yang baru yang belum pernah dirasakan serta menikmati keunikan-keunikan budaya yang ada. Pariwisata Bali dengan segala perkembanganya telah menyumbang penghidupan bagi masyarakat Bali. Keramahtamahan penduduknya merupakan modal dasar bagi perkembangan kepariwisataan di Bali sebagai daya tarik wisatawan untuk berkunjung.

Adapun jumlah kunjungan wisatawan mancanegara dan domestik yang lansung datang ke Bali dalam lima tahun terakhir (2013-2017) dapat dilihat pada Tabel 1.1

Tabel 1 Data Kunjungan Wisatawan Mancanegara dan Domestik Yang Datang Ke Bali Tahun, 20132017

\begin{tabular}{ccccc}
\hline \multirow{2}{*}{ Tahun } & \multicolumn{2}{c}{ Jumlah Wisatawan (Orang) } & \multicolumn{1}{c}{$\begin{array}{c}\text { Total } \\
\text { Wisata wan } \\
(\text { Orang) }\end{array}$} & $\begin{array}{c}\text { Tingkat } \\
\text { Pertumbuhan } \\
(\%)\end{array}$ \\
\cline { 2 - 3 } & Manca Negara & Domestik & 9.012 .890 & - \\
\hline 2012 & 6.063 .558 & 2.949 .332 & 10.255 .134 & 13,78 \\
\hline 2013 & 3.278 .598 & 6.976 .536 & 10.159 .098 & $(0,93)$ \\
\hline 2014 & 3.766 .638 & 6.972 .307 & 11.148 .935 & 9,74 \\
\hline 2015 & 4.001 .835 & 7.147 .100 & 13.571 .617 & 21,73 \\
\hline 2016 & 4.927 .936 & 8.643 .680 & 14.433 .372 & 6,34 \\
\hline 2017 & 5.697 .739 & 8.735 .633 & 8,75 \\
\hline \multicolumn{5}{c}{ Rata-rata Pertumbuhan }
\end{tabular}

Sumber: BPS Provinsi Bali, (2018)

Berdasarkan pada Tabel 1 jumlah kunjungan wisatawan mancanegara dan nusantara mengalami penurunan dan peningkatan. Berdasarkan tabel di atas dapat dilihat bahwa rata-rata jumlah kunjungan wisatawan mancanegara dari tahun 2013-2017 adalah sebesar 8,75\%, Pada tahun 2014 penurunan jumlah kunjungan wisatawan terjadi sebesar $(0,93)$ persen. Penurunan terjadi pada kunjungan wisatawan domestik akibat dari nilai tukar uang jatuh, harga kebutuhan pokok meningakat dan terjadi persaingan pasar wisata di beberapa negara berkembang. Sedangkan di tahun 2017 hanya terjadi sedikit peningkatan jumlah kunjungan wisatawan yaitu sebesar 6,34\%. Tahun 2017 merupakan tahun yang sulit untuk Bali, hal ini terjadi karena meletusnya Gunung Agung.

Gunung Agung terus menerus Aktif dan mengeluarkan asap tebal pada 21 November 2017 yang menyebabkan ribuan orang mengungsi dan menggangu perjalanan udara, hingga tingkat siaga pada level tertinggi, akibatnya lima negara yaitu Selandia Baru, irlandia, Singapura, Australia dan Inggris telah mengeluarkan travel advice ke Bali saat Gunung Agung berstatus Awas pada 22 September 2017 (Byomantara, 2017) Letusan Gunung Agung terakhir terjadi tanggal 3 Juli 2018 dan kini aktivitas pariwisata Bali kembali normal. Akibat terjadi bencana alam seperti meletusnya Gunung Agung, jumlah kunjungan wisatawan ke Bali semakain menurun, seharusnya terjadi high season kunjungan wisatawan mulai bulan November hingga Desember untuk menyambut hari Natal dan pergantian tahun, hal ini menyebabkan penurunan jumlah kedatangan wisatawan pada tahun 2017 dan 
sebaiknya dapat dijadikan acuan bagi pemerintah dan pelaku pariwisata untuk terus mempromosikan Bali sebagai daerah tujuan wisata.

Kabupaten Badung merupakan salah satu kabupaten dengan pendapatan daerah yang tertinggi di Bali dikarenakan keberadaan sarana dan prasarana pariwisata berupa hotel di Kabupaten Badung yang menjadi pusat pembagunan hotel di Bali Selatan. Pada tahun 2016 tercatat ada 219 hotel berbintang di Kabupaten Badung (Disparda Bali, 2016). Sebagian besar hotel berbintang di Kabupaten Badung berada di wilayah selatan.

Adapun jumlah kunjungan wisatawan yang Berkunjung ke Sea Fire Salt Bar di Anantara Uluwatu Resort \& Spa Bali Tahun 2018 dapat dilihat pada Tabel 2

Tabel 2 Data Kunjungan Wisatawan Yang Berkunjung Ke Sea Fire Salt Bardi Anantara Uluwatu Resort \& Spa Bali Pada Tahun 2018

\begin{tabular}{cccc}
\hline No & Bulan & $\begin{array}{c}\text { Jumlah wisatawanyang } \\
\text { Berkunjung(Orang) }\end{array}$ & Pertumbuhan (\%) \\
\hline 1 & Januari & 775 & - \\
\hline 2 & Februari & 992 & 28 \\
\hline 3 & Maret & 1.085 & 9,37 \\
\hline 4 & April & 1.240 & 14,65 \\
\hline 5 & Mei & 744 & -40 \\
\hline 6 & Juni & 310 & $-58,33$ \\
\hline 7 & Juli & 340 & 9.67 \\
\hline 8 & Agustus & 434 & 27,64 \\
\hline 9 & September & 465 & 7,14 \\
\hline & Rata-rata & 6.385 & $-1,86$
\end{tabular}

Sumber: Sea Fire Salt Bar, Anantara Uluwatu Resort \& Spa Bali, 2018

Berdasarkan Tabel 2 di atas dapat disimpulkan bahwa tingkat kunjungan wisatawan ke Sea Fire Salt Bar mengalami fluktuasi. Dapat dilihat di bulan April kunjungan wisatawan ke Sea Fire Salt Bar mengalami peningkatan sekitar 1.240 orang atau 14,65 \% pertumbuhan dikarenakan Sea Fire Salt Bar mendapat event wedding dinner setiap minggunya dan Di bulan Juni telah terjadi penurunan jumlah kunjungan ke Sea Fire Salt Bar yaitu -58,33\% dikarenakan di bulan juni outlet 360 Roof Top Restaurant mengadakan promo food \& beverage sehingga kebanyakan wisatawan mengunjungi promo tersebut. adapun yang menjadi daya tarik tersendiri bagi wisatawan untuk berkunjung adalah kualitas pelayanan yang diberikan Bartender/bartendres di Sea Fire Salt Bar. Kualitas pelayanan yang diberikan mempengaruhi tingkat kepuasan wisatawan yang berkunjung.

Adapun keluhan yang diterima oleh Sea Fire Salt Bar selama bulan Januari-September dapat dilihat dari Tabel 3 berikut :

Tabel 3 Keluhan Wisatawan Terkait Pelayanan Bartender/Bartendres Terhadap Kepuasan Wisatawan Pada Sea Fire Salt Bar Di Anantara Uluwatu Resort \& Spa Bali Tahun 2018.

\begin{tabular}{|c|c|c|c|c|c|c|c|c|c|}
\hline \multirow[t]{2}{*}{ Jenis Keluhan } & \multicolumn{8}{|c|}{ Bulan } & \multirow{2}{*}{$\begin{array}{l}\text { Jumlah } \\
\text { Keluhan }\end{array}$} \\
\hline & Jan & \begin{tabular}{|l|l|} 
Feb & Mar \\
\end{tabular} & Apr & Mei & uni & Juli & Aug & Sep & \\
\hline
\end{tabular}




\begin{tabular}{|l|c|c|c|c|c|c|c|c|c|c|}
\hline $\begin{array}{l}\text { Kecepatan } \\
\text { penyajian minuman } \\
\text { yang la mbat }\end{array}$ & 2 & 3 & 4 & 2 & 3 & 3 & 2 & 2 & 2 & 23 \\
\hline $\begin{array}{l}\text { Pengetahuan } \\
\text { Produk minuman } \\
\text { yang kurang }\end{array}$ & 2 & 1 & 1 & 1 & 2 & 2 & 3 & 2 & 1 & 15 \\
\hline $\begin{array}{l}\text { Rasa minuman yang } \\
\text { tidak konsisten }\end{array}$ & 2 & 1 & 2 & 1 & 1 & 3 & 2 & 2 & 1 & 17 \\
\hline Jumlah Per Bulan & $\mathbf{6}$ & $\mathbf{5}$ & $\mathbf{7}$ & $\mathbf{4}$ & $\mathbf{6}$ & $\mathbf{8}$ & $\mathbf{7}$ & $\mathbf{6}$ & $\mathbf{4}$ & $\mathbf{5 5}$ \\
\hline
\end{tabular}

Sumber: Sea Fire Salt Bar, Anantara Uluwatu Resort \& Spa Bali, 2018

Berdasarkan keluhan tamu (guest comment) dari Tabel 3 di atas yang sering terjadi pada Sea Fire Salt Bar, yaitu:

Kecepatan penyajian yang lambat dari bulan Januari sampai September terdapat 23 jumlah keluhan, Kecepatan penyajian minuman yang dibuat oleh bartender/bartendres manjadi salah satu aktivitas utama setiap bartender/bartendres. Dalam lingkungan bar, kecepatan dalam menyajikan minuman merupakan hal utama yang harus diperhatikan terutama dalam pekerjaan yang menawarkan pelayanan jasa. Kecepatan penyajian minuman yang kurang cepat sangat sering terjadi di Sea Fire Salt Bar, terutama di saat sore menjelang waktu sunset dan keterlambatan ini terjadi karena ramenya pengunjung dan kurangnya staff yang menyajikan minuman sehingga terjadi penumpukan orderan yang masuk dan akhirnya wisatawan menunggu minumanya terlalu lama dan memilih untuk meninggalkan Sea Fire Salt Bar.

Pengetahuan Produk yang Kurang dari Bulan Januari sampai September terdapat 15 jumlah keluhan, Ilmu mengetahui produk minuman yang dijual sangat penting bagi bartender/bartendres untuk membantu wisatawan dalam menentukan pilihan yang akan di minum. Kurangnya pengetahuan tentang minuman membuat wisatawan kurang puas dalam memilih minuman, sehingga menyebabkan wisatawan yang memesan minuman terpaksa merasakan minuman yang sama dikarenakan bayank bartender/bartendres yang masih baru dalam menyajikan minuman padahal sudah berhadapan lansung dengan tamu, permasalahan tersebut seperti di atas sering terjadi pada Sea Fire Salt Bar dan hal ini berdampak serius karena memiliki efek lansung pada nama baik Anantara Uluwatu Resort \& Spa Bali.

Rasa minuman yang tidak konsisten dari bulan Januari sampai September terdapat 17 jumlah keluhan Sebagian besar keluhan yang dilakukan wisatawan diakibatkan karena rasa minuman yang tidak konsisten di Sea Fire Salt Bar. Beberapa konsumen cenderung hanya menyampaikan keluhannya tersebut dengan harapan mendapatkan minuman baru atau bahkan gratis untuk kegagalan jasa yang dialaminya. Terjadi karena kelalaian Bartendr/bartendres yang tidak fokus dalam menyajikan minuman atau pekerjaan yang ditekuninya. Sehingga Beberapa wisatawan yang tidak puas mengeluh dengan tegas seperti meminta untuk memanggil supervisor atau bahkan memanggil manager inchage.

Terjadinya masalah pada sebuah Bar dapat mengurangi nilai jual pada suatu Bar dan berdampak pada penilaian hotel tersebut. Semakin tinggi nilai yang diberikan wisatawan maka semakin tinggi pula nilai harga jual hotel tersebut dan juga semakin bayanak wisatawan yang menginap dan minum di Bar dan kamar hotel tersebut. Kualitas pelayanan di Anantara Uluwatu Resort \& Spa Bali tidak dapat dipandang sebelah mata, karena hotel ini telah memiliki track record yang hampir dikatakan sempurna di mata masyarakat umum atau wisatawan mancanegara dan salah satu perusahaan perhotelan dan rekreasi terbesar di Asia, dengan lebih dari 30 perusahaan yang berfokus pada tiga bisnis utama termasuk restoran, hotel, dan merek gaya hidup. Selain itu memiliki beberapa cabang tidak hanya Anantara, di antaranya AVANI, Per Aquum, Oaks, Tivoli, Elewana, dan masih banyak lagi yang sudah tersebar di beberapa Negara, seperti: Maldieves, Unites Emirates Arab (UAE), China, dan termasuk 
Indonesia. Anantara Hotel pertama kali berdiri pada tahun 2001 di Hua Hin, Thailand dengan nama hotel Anantara Thailand.

\section{METODE PENELITIAN}

Anantara Uluwatu Resort \& Spa Bali merupakan salah satu hotel bintang lima yang terletak di kawasan Uluwatu, sekitar 40 menit dari Bandara Internasional Ngurah Rai. Berikut ini merupakan alamat lengkap dari Anantara Uluwatu Resort \& Spa Bali :

Alamat : J1. Pemutih, Labuan Sait, Uluwatu 80364, Bali, Indonesia.
Telepon
: (0361) 8957555

3.2.1 Fax : (0361) 8957600

E-mail : uluwatu@anantara.com

Website : www.anantara.com

Facebook : : Anantara Uluwatu Resort \& Spa Bali .

Instagram : anantarauluwatu

\subsection{Kualitas Pelayanan Bartender/Bartendres}

Kualiatas pelayanan dalam penelitian ini adalah penilaian pelanggan terhadap kualitas pelayanan yang diterima dengan tingkat pelayanan yang diharapkan. Kualitas pelayana bartender/bartendres dapat diukur menggunakan 5 indikator yang meliputi kepuasan wisatawan pada Sea Fire Salt Bar di Anantara Uluwatu Resort \& Spa Bali yang digunakan dalam penelitian ini, antara lain.

Tabel 4 Definisi Operasional Variabel Analisis Kualitas Pelayanan Bartender/Bartendres Dalam Meningkatkan Kepuasan Wisatawan Pada Sea Fire Salt Bar Di Anantara Uluwatu Resort \& Spa Bali

\begin{tabular}{|c|c|c|}
\hline No & Indikator & Sub Indikator \\
\hline 1 & $\begin{array}{l}\text { Bukti Fisik } \\
\text { (tangible) }\end{array}$ & $\begin{array}{l}\text { a. Kelengka pan dan kebersihan fasilita s } \\
\text { bartender/bartendres. } \\
\text { b. Kelengkapan dan kebersihan alat bartender/bartendres. }\end{array}$ \\
\hline 2 & $\begin{array}{l}\text { Kepedulian } \\
\text { (Empathy) }\end{array}$ & $\begin{array}{l}\text { a. Kema mpuan bartender/bartendres untuk memahami } \\
\text { kebutuhan wisatawan } \\
\text { b. Kema mpuan bartender/bartendres untuk membina } \\
\text { hubungan baik dengan wisa tawan } \\
\text { c. Kema mpuan bartender/bartendres untuk memberikan } \\
\text { perhatian khusus kepada wisa tawan, seperti } \\
\text { menginformasikan kadar a lkohol yang terkandung dalam } \\
\text { minuman serta menanyakanjika a da yang a lergidan } \\
\text { memerlukan special request. }\end{array}$ \\
\hline 3 & $\begin{array}{l}\text { Keandalan } \\
\text { (Reliability) }\end{array}$ & $\begin{array}{l}\text { a. Keandalan dalam menjelaskan produk oleh } \\
\text { bartender/bartendres. } \\
\text { b. Kecepatan dan Ketepatan waktu dalam proses penyajian } \\
\text { makanandan minuman. } \\
\text { c. Kema mpuan bartender/bartendres dalam penguasaan } \\
\text { bahasa a sing serta dapat berkomunikasi dengan baik pada } \\
\text { wisata wan. }\end{array}$ \\
\hline 4 & $\begin{array}{l}\text { Ketanggapan } \\
\text { (Responsiveness) }\end{array}$ & $\begin{array}{l}\text { a. Kecepatan dan usaha bartender/bartendres dalam } \\
\text { mengatasi keluhan wisatwan. } \\
\text { b. Kesiapan bartender/bartendres dalam membantu dan } \\
\text { memberikan pelayanan. } \\
\text { c. Sikap bartender/bartendres saat memberikan pelayanan } \\
\text { kepada wisatwan. }\end{array}$ \\
\hline
\end{tabular}




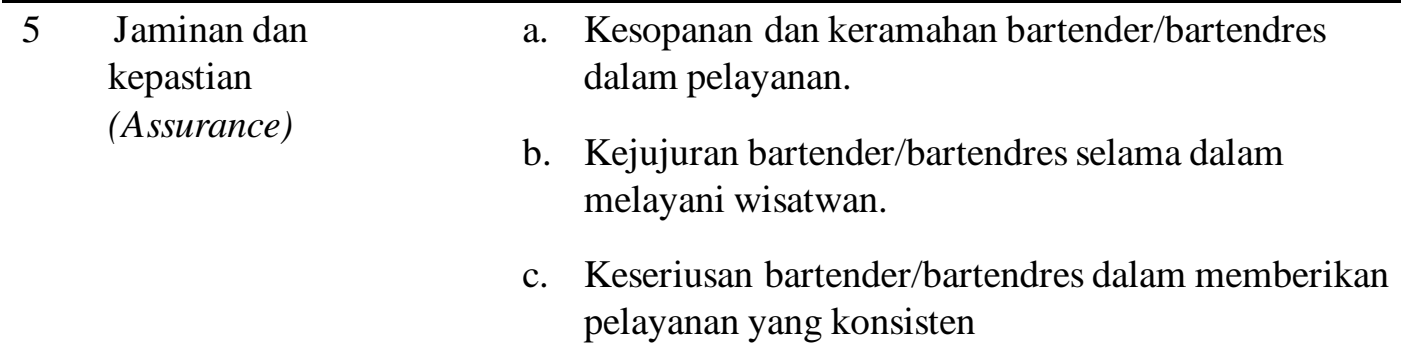

Sumber: Hasil Modifikasi Pa rasuraman,Zeithaml,Dan Berry(1985)

\subsection{Kepuasan Pelanggan}

Kepuasan Wisatawan adalah suatu keadaan yang dirasakan setelah tamu mendapatkan pelayanan dari bartender/bartendres dengan membandingkan kinerja (performance) dan kepentingan (importance) yang diukur menggunakan indikator-indikator kualitas pelayanan.

\section{HASIL DAN PEMBAHASAN}

\subsection{Gambaran Umum Anantara Uluwatu Resort \& Spa Bali}

Anantara Uluwatu Bali Resort merupakan salah satu brands dari Minor Group yaitu sebuah perusahaan yang bergerak di bidang hospitality. Minor Group didirikan oleh Mr. Wiliam Ellwood Heinecke pada tahun 1978 dengan Royal Garden Resort di Pattaya. Sekarang Minor International Plc adalah salah satu perusahaan perhotelan dan rekreasi terbesar di Asia, dengan lebih dai 30 perusahaan yang berfokus pada tiga bisnis utama termasuk restoran, hotel, dan merek gaya hidup. MINOR Hotel Group memiliki beberapa cabang tidak hanya Anantara, di antaranya AVANI, Per Aquum, Oaks, Tivoli, Elewana, dan masih banyak lagi yang sudah tersebar di beberapa Negara, seperti: Maldieves, Unites Emirates Arab (UAE), China, dan termasuk Indonesia. Anantara Hotel pertama kali berdiri pada tahun 2001 di Hua Hin, Thailand dengan nama hotel Anantara Thailand. Jarak Sea Fire Salt Bar Anantara Uluwatu Resort \& Spa Bali ke Bandara Internasional Ngurah Rai Sekitar 20 km yang membutuhkan waktu kurang lebih 30 menit bila ditempuh dengan kendaran bermotor, sedangkan dari pusat kota Denpasar menuju ke hotel membutuhkan waktu kurang lebih 60 menit dengan jarak tempuh sekitar $30 \mathrm{~km}$. Terletak di bagian selatan Bali, di daerah pariwista Uluwatu, terletak di atas tebing setinggi 40 meter dengan pemandangan Samudra Hindia yang memukau.

\subsection{Sejarah Berdirinya Anantara Uluwatu Resor \& Spa Bali}

Anantara berasal dari bahasa Sansekerta yang artinya 'without end' atau tanpa akhir. Hal ini menggambarkan kebebasan, perkembangan, dan keserasian dalam semangat melayani. Setiap Anantara Resort menggabungkan kekayaan budaya, warisan sejarah dan keindahan alam di tiap-tiap tempatnya berdiri. Anantara Tahiland berupaya membawa setiap orang mendekati kekayaan budaya dan sejarah Thailand dengan membaurkan mereka dengan kehidupan tradisional Thailand.

Beberapa tahun yang lalu orang-orang Thailand meletakkan guci yang berisi air di depan rumah mereka untuk para wistawan yang melintas guna melegakan haus mereka. Air di dalam guci tersebut terus diisi ulang jika sudah mulai habis. Orang-orang Thailand sangat bersemangat mengisi guci tersebut dengan air. Seiring dengan berjalannya waktu, air di dalam guci tersebut dijadikan panutan dari keramah-tamahan.

Di Thailand mengisi air di dalam guci tersebut disebut dengan istilah "Nahm Jai" atau "Water From The Heart ". Istilah ini berarti "Giving without expecting in return" atau memberi dengan tulus iklas. Lambang Anantara sendiri terdiri dari guci dan bantal. Guci ini berarti keikhlasan, sedangkan bantal tersebut memiliki arti ketenangan atau kenyamanan. Jadi, lambang Anantara tersebut bermakna 
Anantara akan melayani dengan kenyamanan dan ketenangan selama menginap di Anantara yang tulus dari hati melalui budaya lokal. Sejak saat itu, Anantara terus mengembangkan pelayanannya di luar Thailand dengan selalu membawa keunikan arti dari lambangnya untuk memulai di tempat tujuan yang lebih luas, yakni Asia dan Timur. Anantara senantiasa berkeyakinan melalui semangatnya untuk mengembangkan setiap kebudayaan dunia.

Anantara Uluwatu Resort \& Spa Bali sendiri sudah berdiri sejak 15 Juni 2012 yang berlokasi di Uluwatu, Bali yaitu di atas tebing curam yang menghadap langsung ke Samudera Hindia dengan pemandangan langit biru, sunset serta ombak yang memukau mata. Semua tamu yang menginap di Anantara diharapkan pulang membawa pengalaman yang benar-benar menakjubkan setelah menginap di Anantara Bali Uluwatu Resort \& Spa Bali.

\subsection{Karakteristik Wisatawan}

Tabel 5 Karakteristik Wisatawan Di Sea Fire Salt Bar Anantara Uluwatu Resort \& Spa Bali

\begin{tabular}{|c|c|c|c|}
\hline No & Jenis Kelamin & Jumlah(orang) & Persentase (\%) \\
\hline $\mathbf{1}$ & Laki-laki & 67 & 67 \\
\hline 2 & Perempuan & 33 & 33 \\
\hline No & Tingkat Umur (Tahun) & Jumlah (Orang) & Persentase (\%) \\
\hline $\mathbf{1}$ & $<25$ & 18 & 18 \\
\hline 2 & $26-35$ & 20 & 20 \\
\hline 3 & $36-45$ & 40 & 40 \\
\hline 4 & $>46$ & 22 & 22 \\
\hline No. & Frekuensi Kunjungan & Jumlah (Orang) & Persentase (\%) \\
\hline 1 & Pertama & 62 & 62 \\
\hline 2 & $2-5$ & 28 & 28 \\
\hline 3 & $>6$ & 10 & 10 \\
\hline No. & Pekerjaan & Jumlah (Orang) & Persentase (\%) \\
\hline 1 & PNS & 10 & 10 \\
\hline 2 & Swasta & 28 & 28 \\
\hline 3 & Wiraswasta & 39 & 39 \\
\hline 4 & Pelajar & 15 & 15 \\
\hline 5 & Tidak Bekerja & 6 & 6 \\
\hline 6 & Lainnya & 2 & 2 \\
\hline
\end{tabular}




\begin{tabular}{|c|c|c|c|}
\hline No. & Asal Negara & Jumlah (orang) & Persentase $(\%)$ \\
\hline 1 & Australia & 21 & 21 \\
\hline 2 & Italia & 4 & 4 \\
\hline 3 & England & 2 & 2 \\
\hline 4 & Indonesia & 15 & 15 \\
\hline 5 & Denmark & 4 & 4 \\
\hline 6 & France & 5 & 5 \\
\hline 7 & Netherlands & 2 & 2 \\
\hline 8 & Austria & 2 & 2 \\
\hline 9 & Singapura & 4 & 4 \\
\hline 10 & Malaysia & 2 & 2 \\
\hline 11 & Japan & 6 & 6 \\
\hline 12 & Selandia Baru & 2 & 2 \\
\hline 13 & Arab Saudi & 3 & 3 \\
\hline 14 & Germany & 3 & 3 \\
\hline 15 & Amerika Serikat & 4 & 4 \\
\hline 16 & Canada & 2 & 2 \\
\hline 17 & China & 17 & 17 \\
\hline 18 & Russian & 2 & 2 \\
\hline
\end{tabular}

Sumber : Data Diolah Da ri Hasil Kuesioner, 2019

\subsection{Penilaian Tingkat Kesesuaian Antara Kinerja Dan Kepentingan}

Importance peformace analysis (analisis derajat kepentingan-kinerja), ini digunakan untuk mengetahui apakah semua indikator kualitas pelayanan bartender/bartendres yang sudah dilakukan di Sea Fire Salt Bar Anantara Uluwatu Resort \& Spa Bali. Derajat kepentingan dan kinerja di ukur dengan menggunakan skala lima point. Selanjutnya agar dapat mengetahui letak-letak indikator pada diagram kartesius maka terlebih dahulu menentukan dua buah titik X dan Y yang berpotongan membatasi empat bagian dalam diagram katesius

Perhitungan $\mathrm{X}$ merupakan rata-rata dari rata-rata skor tingkat kinerja seluruh indikator yang mempengaruhi kepuasan pelanggan sebagai berikut

$\mathrm{n}$

$\sum X \mathrm{i}$

$X=\underline{1=1}$

K 
Dimana $\mathrm{K}$ adalah banyaknya indikator yang mempengaruhi kepuasan pelanggan yaitu sebanyak 15 sub indikator.

$\mathrm{n}$

$\sum \mathrm{Xi}$

$\mathrm{X}=\underline{1=1}$

$\mathrm{K}$

$=3,95+4,01+3,88+4,41+3,73+3,81+3,82+3,66+4,09+3,91+3,77+3,88+3,48+3,53$

$+3,76$

15

$=3,84$

Perhitungan Y merupakan rata-rata dari rata-rata skor tingkat kepentingan seluruh indikator yang mempengaruhi kepuasan pelanggan sebagai berikut :

$\mathrm{n}$

$\sum \mathrm{Yi}$

$\mathrm{Y}=\underline{1=1}$

$\mathrm{K}$

Dimana $\mathrm{K}$ adalah banyaknya indikator yang mempengaruhi kepuasan pelanggan yaitu sebanyak 15 sub indikator

$\mathrm{n}$

$\sum Y i$

$\mathrm{Y}=\underline{1=1}$

$\mathrm{K}$

$=4,16+4,01+4,07+4,01+4,14+4,26+4,19+3,95+4,24+4,23+4,04+4,14+3,93+$ $3,98+3,91$

15

$=4,15$

Letak pada indikator kualitas pelanyanan bartender/bartendres yang mempengaruhi kepuasan konsumen di Sea Fire Salt Bar Anantara Uluwatu Resort \& Spa Bali dapat dilihat dalam diagram kartesius. 


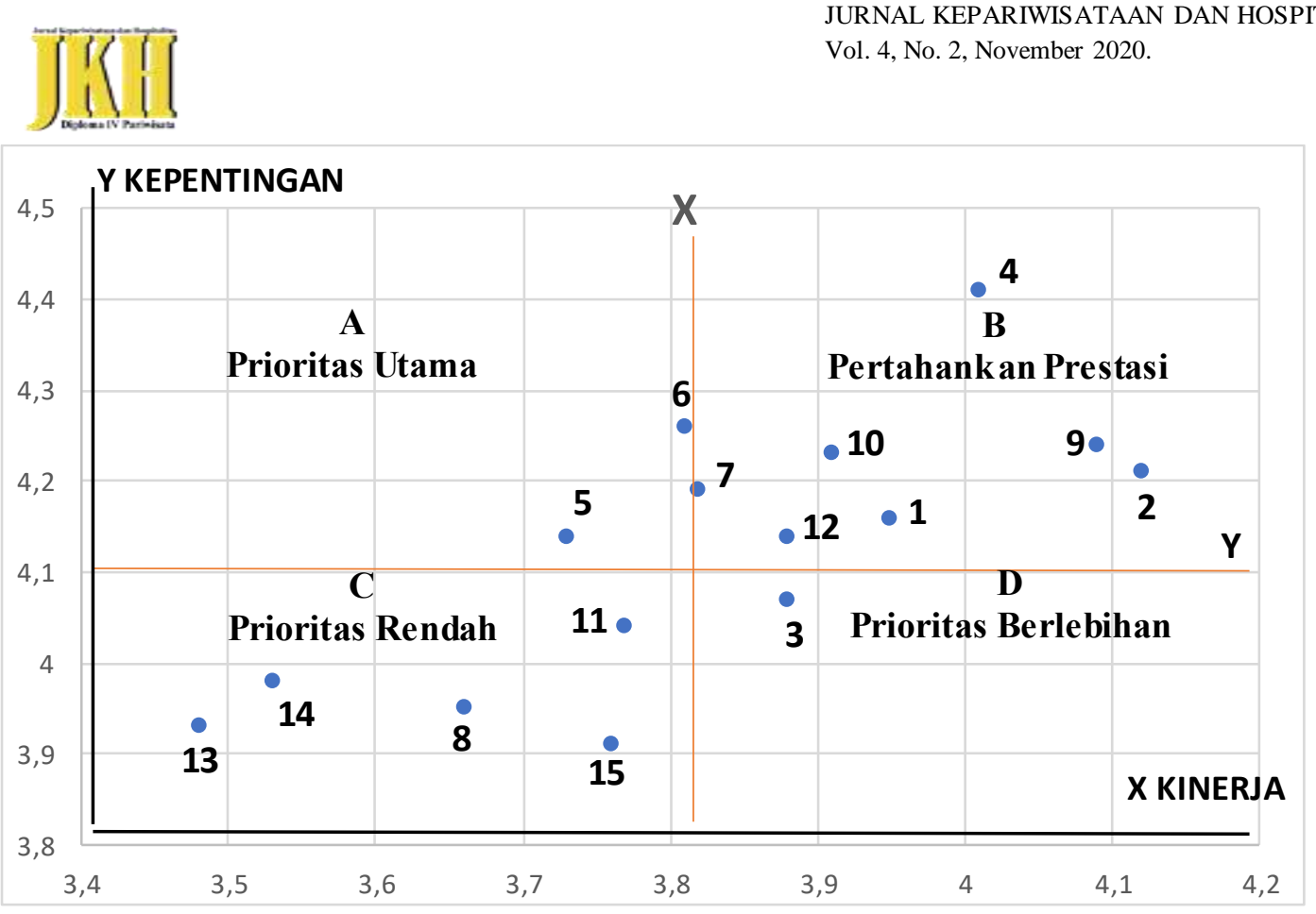

Gambar 1 Diagram Kartesius Indikator Kualitas Pelayanan Barista Yang Berpengaruh Terhadap Kepuasan Konsumen Di Sea Fire Salt Bar Anantara Uluwatu Resort \& Spa Bali

Sumber : Data diolah dari hasil penelitian 2018

Berdasarkan gambar 4.16 terlihat bahwa letak indikator pada pelayanan barista yang mempengaruhi kepuasan konsumen di Sea Fire Salt Bar Anantara Uluwatu Resort \& Spa Bali di bagi dalam empat bagian diagram kartesius diantaranya

1) Kuadran A ( Prioritas Utama)

2) Kuadran B (Prioritas Presta si)

3) Kuadran C (Prioritas Rendah )

4) Kuadran D (Berlebihan)

\section{Kuadran A ( Prioritas Utama )}

Menunjukkan indikator yang dianggap mempengaruhi kepuasan wisatawan yang berkunjung ke di Sea Fire Salt Bar di Anantra Uluwatu Resort \& Spa Bali, termasuk unsur jasa sangat penting, namun pelayanan Bartender/bartendres belum dilaksanakan sesuai keinginan wisatawan, sehingga mengecewakan/tidak puas. Dalam penanganan perlu diprioritaskan oleh pihak Bartender/bartendres, karena keberadaan indikator inilah yang dinilai sangat penting oleh wisatawan, sedangkan tingkat pelaksanaannya belum memuaskan. Adapun 2 indikator yang masuk dalam kuadran A adalah sebagai berikut:.

1) Kema mpuan bartender/bartendres untuk memberikan perhatian khusus kepada wisa tawan ( 5 )

2) Keandalan dalam menjelaskan produk oleh bartender/bartendres (6)

Kuadran B ( Prioritas Prestasi )

Menunjukkan bahwa jasa pokok yang diberikan oleh Bartender/bartender di Sea Fire Salt Bar di Anantra Uluwatu Resort \& Spa Bali telah berhasil dilaksanakan untuk itu perlu terus dan wajib dipertahankan. Pada umumnya tingkat kualitas pelayanan sangat penting dan sangat memuaskan. Adapun 7 indikator yang masuk dalam kuadran B adalah sebagai berikut.

1) Kelengkapan dan kebersihan fasilita s bartender/bartendres ( 1 )

2) Kelengkapan dan kebersihan alat bartender/bartendres (2)

3) Kema mpuan bartender/bartendres untuk membina hubungan baik dengan wisatawan (4)

4) Kecepatan dan Ketepatan waktu dalam proses penyajian makanan dan minuman pelanggan (7) 
5) Kecepatan dan usaha bartender/bartendres dalam mengatasi keluhan wisatawan (9)

6) Kesiapan bartender/bartendres dalam membantu dan memberikan pelayanan (10)

7) Kesopanan dan keramahan bartender/bartendres dalam pelayanan(12)

\section{Kuadran C ( Prioritas Rendah )}

Menunjukkan beberapa indikator yang kurang penting pengaruhnya bagi wisatawan, pelaksanaan oleh perusahaan biasa-biasa saja. Dianggap kurang penting dan kurang memuaskan. Adapun 5 indikator yang masuk dalam kuadran $\mathrm{C}$ adalah sebagai berikut:

1) Kema mpuan bartender/bartendres da lam penguasaan bahasa a sing serta dapat berkomunikasi den gan baik pada wisatawan ( 8 )

2) Sikap bartender/bartendres saat memberikan pelayanan kepada wisatwan (11)

3) Kejujuran bartender/bartendres selama dalammelayani wisa twan (13)

4) Keseriusan bartender/bartendres dalammemberikan pelayanan yang konsisten (14 )

5) Informasi yang diberikan bartender/bartendres sesuai dengan harapan a tau melebihi ha rapan (15)

\section{Kuadran D ( Berlebihan )}

Menunjukkan indikator yang bagi wisatawan yang berkunjung dianggap kurang penting, akan tetapi pada pelaksanaannya berlebihan. Dianggap kurang penting tetapi memuaskan. Adapun indikator yang masuk dalam kuadran D adalah sebagai berikut:

1) Kema mpuan bartender/bartendres untuk memahami kebutuhan wisatawan ( 3 )

\subsection{Prioritas Berdasarkan Tingkat Kepuasan}

Untuk mengetahui indikator- indikator mana yang perlu dan mendapatkan prioritas utama dalam sebuah pelayanan Bartender/bartendres dapat dilakukan dengan cara mengurutkan tingkat kesesuaian yang diperoleh. Semakin rendah tingkat kesesuaian maka semakain perlu indikator yang dimaksud mendapatkan prioritas demikian juga sebaliknya, semakin tinggi kesesuaian indikator yang dimaksud maka semakin rendah pula prioritas indikator tersebut. Tingkat kepuasan wisatawan terhadap pelayanan bartender/bartendres di Sea Fire Salt Bar dapat di lihat pada Tabel 4.8 di bawah ini.

Tabel 6 Urutan Prioritas Indikator-Indikator Kualitas Pelayanan Bartender/bartendres di Sea Fire Salt Anantara Uluwatu Resort \& spa Bali Yang Mempengaruhi Tingkat Kepuasan Wisatawan.

\begin{tabular}{llcc}
\hline No & \multicolumn{1}{c}{ Indikator } & Tingkat Kesesuaian & Prioritas \\
\hline 1 & $\begin{array}{l}\text { Kejujuran bartender/bartendres selama } \\
\text { dalam melayani wisatwan(13) }\end{array}$ & I \\
\hline 2 & $\begin{array}{l}\text { Keseriusan bartender/bartendres dalam } \\
\text { memberikan pelayanan yang konsisten } \\
(14)\end{array}$ & $88.54 \%$ & II \\
\hline 3 & $\begin{array}{l}\text { Keandalan dalam menjelaskan produk } \\
\text { oleh bartender/bartendres (6) }\end{array}$ & III \\
\hline 4 & $\begin{array}{l}\text { Kemampuan bartender/bartendres } \\
\text { untuk memberikan perhatian khusus } \\
\text { kepada wisatawan(5) }\end{array}$ & IV \\
\hline 5 & $\begin{array}{l}\text { Kelengkapan dan kebersihan alat } \\
\text { bartender/bartendres (2) }\end{array}$ & $90.43 \%$ & V \\
\hline 6 & $\begin{array}{l}\text { Kecepatan dan Ketepatan waktu dalam } \\
\text { proses penyajian makanandan } \\
\text { minuman(7) }\end{array}$ & $90.92 \%$ & VI \\
\hline 7 & $\begin{array}{l}\text { Kesiapan bartender/bartendres dalam } \\
\text { membantu dan memberikan pelayanan } \\
\text { (10) }\end{array}$ & $91,16 \%$ & VII \\
\hline
\end{tabular}




\begin{tabular}{|c|c|c|c|}
\hline 8 & $\begin{array}{l}\text { Kemampuan bartender/bartendres } \\
\text { dalam penguasaan bahasa a sing serta } \\
\text { dapat berkomunikasi dengan baik pada } \\
\text { wisata wan }(8)\end{array}$ & $92,65 \%$ & V1II \\
\hline 9 & $\begin{array}{l}\text { Sikap bartender/bartendres saat } \\
\text { memberikan pelayanan kepada } \\
\text { wisatwan }(11)\end{array}$ & $93.31 \%$ & IX \\
\hline 10 & $\begin{array}{l}\text { Kesopanan dan keramahan } \\
\text { bartender/bartendres dalam pelayanan } \\
\text { (12) }\end{array}$ & $93.71 \%$ & $X$ \\
\hline 11 & $\begin{array}{l}\text { Kelengkapan dan Kebersihan fasilitas } \\
\text { bartender/bartendres (1) }\end{array}$ & $94,95 \%$ & XI \\
\hline 12 & $\begin{array}{l}\text { Kemampuan bartender/bartendres } \\
\text { untuk memahami kebutuhan wisa tawan } \\
\text { (3) }\end{array}$ & $95.33 \%$ & XII \\
\hline 13 & $\begin{array}{l}\text { Informasi yang diberikan } \\
\text { bartender/bartendres sesuai dengan } \\
\text { hara pan atau melebihi harapan }(15)\end{array}$ & $96.41 \%$ & X111 \\
\hline 14 & $\begin{array}{l}\text { Kecepatan dan usaha } \\
\text { bartender/bartendres dalam mengatasi } \\
\text { keluhan wisa tawan }(9)\end{array}$ & $96,46 \%$ & XIV \\
\hline 15 & $\begin{array}{l}\text { Kemampua bartender/bartendres untuk } \\
\text { membina hubungan baik dengan } \\
\text { wisata wan (4) }\end{array}$ & $97.86 \%$ & XV \\
\hline
\end{tabular}

Sumber: Da ta Diolah Dari Hasil Kuesioner, 2019

\subsection{Tingkat Kepuasan Wisatawan Terhadap Pelayanan Barartender/Bartendres Di Sea Fire Salt Bar Anantara Uluwatu Resort \& Spa Bali}

Berdasarkan analisis tingkat kesesuaian yang dilakukan pada indikator pelayanan Bartender/bartendres yang mempengaruhi tingkat kepuasan wisatawan pada Tabel di atas, maka diperoleh tingkat kepuasan wisatawan terhadap seluruh indikator dengan cara membagi jumlah tingkat kesesuaian dengan banyaknya indikator pelayanan. Jadi tingkat kepuasan wisatawan sebagai berikut

Tingkat Kepuasan $=\sum$ Tki

$$
\begin{gathered}
\frac{\mathrm{K}}{} \\
=88,54 \%+88,69 \%+89,43 \%+90,09 \%+90.92 \%+91.16 \%+92.43 \%+92.64 \%+93.31 \%+93.71 \% \\
+94.95 \%+95.33 \%+96.16 \%+96.46 \%+97.86 \% \\
\hline
\end{gathered}
$$

$=92,77 \%$

Berdasarkan perhitungan di atas maka diperoleh tingkat kepuasan wisatawan terhadap pelayanan bartender/bartendres pada Sea Fire Salt Bar Anantara Uluwatu Resort \& Spa Bali sebesar $92.77 \%$, dengan demikian dapat disimpulkan bahwa wisatawan puas terhadap pelayanan Bartender/bartendres.

Oleh karena itu, pihak manajemen Food \& Beverage Departmen perlu mempertahankan pelayanan yang telah di berikan. Meskipun demikian, namun masih ada beberapa indikator yang perlu ditingkatkan prioritasnya sehingga pelayanan yang diberikan akan lebih baik. 


\section{KESIMPULAN}

Berdasarkan hasil dan pembahasan pada BAB IV dapat disimpulakan tentang Analisis Kualitas Pelayanan Bartender/Bartendres Dalam Meningkatkan Kepuasan Wisatawan Pada Sea Fire Salt Bar Di Anantara Uluwatu Resort \& Spa Bali maka dapat diambil kesimpulan sebagai berikut.

1. Berdasarkan hasil perhitungan persepsi wisatawan terhadap kinerja bartennder/bartendres di Anantra Uluwatu Resort \& Spa Bali yaitu berdasarkan perhitungan Skala Likert dari 100 responden, bahwa secara keseluruan persepsi wisatawan terhadap kinerja bartender/bartendres pada Anantara Uluwatu Resort \& Spa Bali adalah baik. Dengan rata-rata sikap 3.84. Hasil tertinggi yang didapat adalah persepsi wisatawan terhadap Kemampua bartender/bartendres untuk membina hubungan baik dengan wisatawan yang memperoleh total skor 412 dengan ratarata sikap 4.12 persen yaitu baik. Sedangkan hasil yang paling rendah didapat adalah persepsi terhadap kejujuran bartender/bartendres selama dalam melayani wisatawan yang memperoleh total skor 348 dengan rata-rata sikap sebesar 3.48 persen yaitu baik. Jadi untuk itu diharapkan Sea Fire Salt Bar terus meningkatkan kualitas kinerja yang diberikan kepada wisatawan yang berkunjung sehingga meningkatkan citra yang baik dan bagus di mata pengunjung atau wisatawan yang berkunjung ke Sea Fire Salt Bar di Anantara Uluwatu Resort \& Spa Bali, dimana wisatawan merasa nyaman dan senang menikmati pelayanan yang disediakan.

2. Berdasarkan perhitungan tingkat kepuasan wisatawan terhadap kinerja dan kepentingan Bartender/bartendres pada Sea Fire Salt Bar Anantra Uluwatu Resort \& Spa Bali yang didasarkan atas presepsi wisatawan maka didapatkan tingkat kepuasan wisatawan sebesar 92,77 persen, dengan demikian dapat disimpulkan bahwa wisatawan puas terhadap pelayanan Bartender/bartendres pada Sea Fire Salt Bar di Anantara Uluwatu Resort \& Spa Bali.

\section{DAFTAR PUSTAKA}

https://www.anantara.com/en/uluwatu-bali. Diakses pada tanggal 20 februari 2019.

Disparda Bali. 2019. " Jumlah Kunjungan Wisatwan Mancanegara Ke Bali Tahun 2013-2017'. 'http://disparda.baliprov.go.id/. Diakses tanggal 20 februari 2019

Disparda Bali. 2019. " Jumlah Kunjungan Wisatwan Domestik Ke Bali Tahun 2013-2017'. 'http://disparda.baliprov.go.id/. Diakses tanggal 20 februari 2019.

I Dewa Made Raditya Jayawardana (2012) Yang Berjudul Analisis Kualitas Pelayanan Food \& Beverage Departement Dalam Meningkatkankepuasan Pelanggan Di Golden Tulip Devins Hotel Seminyak Bali. Diakses tanggal 15 Februari 2019.

Kotler, Philip. 2002. Manajemen Pemasaran.Edisi Kedua.Jakarta: Prenhallindo. Diakses tanggal 20 februari 2019.

Tjiptono Fandy (2002: 59), “Kualitas pelayanan (jasa). Diakses tanggal 26 januari 2019.

Parasuraman, Valarie A. Zeithaml A; Berry Leonard L; Delivering Quality Service; Balancing Custumer Perception And Expectations; The Free Press, London 1990. Diakses tanggal 15 Februari, 2019.

Sugiyono.2003. Metode Penelitian Bisnis. Bandung: CV Alfabeta. Diakses tanggal 15 Februari 2019.

Septarini, Erivia Diah. 2012. Analisis Tingkat Kepuasan Konsumen Terhadap Pelayanan Pramusaji Di Jazz Bar and Grille Restaurant Sanur. . Laporan Akhir Program Sarjana Universitas Udayana.

Tindaon, Yosi Abdian. 2012. Pengertian Pengaruh. Dalam http://yosiabdiantindaon.blogspot.co.id diakses tanggal 20 Maret 2019. 
Utama, Bagus Rai dan Eka Mahadewi. 2012. Metodologi Penelitian Pariwisata dan Perhotelan. Yokyakarta: Penertbit Andi. Diakses tanggal 20 Maret 2019.

Supranto, J. (2006 : 242) Pengukuran Tingkat Kepuasan Pelanggan. Jakarta : Rineka Cipta. Diakses tanggal 25 Januari 2019.

Wiantara. I Gusti Nyoman. Drs. MM. 2010. Tanggun jawab dan Kualifikasi seorang Bartender. Diakses tanggal 20 Maret 2019. 